\title{
Enhancing the quality of health education through distance education
}

\author{
SOUJANYA S. HIREMATH* AND UMA S. HIREMATH \\ Department of Extension and Communication Management, College of Rural Home Science, University \\ of Agricultural Sciences, DHARWAD (KARNATAKA) INDIA
}

\begin{abstract}
Distance education in India is making it easier to close the educational gap between rural and urban areas. By making educational opportunities easily available to everyone, distance education is opening up career options for the less privileged segments of Indian population. An experimental study was conducted to enhance the quality of health education through distance education with the objective to assess the knowledge of rural school dropout girls and women at pre and post stage of the distance education. The sample consisted 120 respondents who were selected from four villages namely Harobelawadi, Uppinbetageri, Mansur, Garag of Dharwad taluka. Village wise knowledge of respondents after the education revealed that majority (88\%) of the respondents gave correct answer about family sanitation, followed by personal hygiene (85\%), community sanitation (83.34\%), environmental sanitation $(82.50 \%)$ and additional useful information for rural sanitation (75\%). The knowledge about family sanitation shows that high majority of the respondents answered rightly for importance of proper light and aeration at home, followed by place for washing of pesticide equipments and material used in the gobar gas plant. Cent per cent of the respondents gave correct answer for colostrum feeding and proper washing of hands after toilet. Majority of the respondents answered with respect to spraying of DDT powder to drainage and stagnant water to control mosquitoes, which are the causes of malaria. More than 80 per cent of the respondents were able to answer about methods to burry dead rats and pets, place to keep the milch animals in the house and source of solar cooker. Similarly, majority of the respondents answered rightly about astra chullaha/ or smokeless chullaha and department in-charge to distribute solar cooker.
\end{abstract}

KeY Words : Enhancing, Quality health, Distance education

View Point Article : Hiremath, Soujanya S. and Hiremath, Uma S. (2015). Enhancing the quality of health education through distance education. Internat. J. Home Sci. Extn. \& Comm. Manage., 2 (1): 39-44.

Article History : Received : 19.11.2014; Revised : 01.12.2014; Accepted : 15.12 .2014 